\title{
Evidence of mispricing for South African listed R\&D firms contributed by accounting conservatism
}

\author{
Kutlwano K. K. M. Ramaboa*(D), Tai-Lin G. Chen(D) \\ University of Cape Town, Graduate School of Business (South Africa) \\ ${ }^{*}$ Corresponding author: kuthwano.ramaboa@gsb.uct.ac.za, chntai002@gsb.uct.ac.za
}

Received September, 2015

Accepted January, 2016

\section{Abstract}

Purpose: The purpose of this research is to investigate the impact of capitalization of research and development on the valuation of equities for listed firms in South Africa.

Design/methodology: 15 years of financial data (2000 to 2014) was collected, and portfolios with similar price-to-book and market size ratios were formed to find any evidence of any postinvestment excess returns and the association to the level of research and development investment. Portfolios were re-formed and annually ranked by their research and development intensity relative to sales. In addition, we looked at the changes in excess returns after adjusting the book value as a result of capitalizing $\mathrm{R} \& \mathrm{D}$ expenditure, to see if the distortion imposed by expensing $\mathrm{R} \& \mathrm{D}$ contributed to the under-valuation of firms that invest in $\mathrm{R} \& \mathrm{D}$.

Findings: The results indicate that firms that invest in research and development are systematically under-valued. We found no evidence of any positive association between the post-investment excess returns and investment levels, but rather found evidence of the glamour stock phenomenon in highly intensive research and development firms.

Research limitations/implications: The sample data is limited to listed firms in South Africa, and for firms with intermittently omitted $R \& D$ on their financial report, we have assumed that such expenditure is zero for the non-disclosed period for the purpose of capitalization and 
amortisation. Listed firms whose main focus is on building intangible assets, are relatively few, hence our research is descriptive in nature.

Practical implications: This paper highlights the commercial significance of valuing the longterm benefits of research and development. Capitalizing the development phase as afforded by the IASB lacks standardization, and as such, inconsistencies arise in the earnings reflected on companies' financial statements. For investors though, highly intensive R\&D firms should be avoided as these earn negative returns.

Originality/value: The authors are not aware of any studies showing the effect of accounting rules on research and development that have been conducted in South Africa, or any research that have shown the glamour stock phenomena when investigating the impact of capitalization of research and development. Thus our contribution was to provide evidence on the valuation of stocks for listed firms that report research and development in South Africa that may be a result of the accounting rules. There is limited research on the accounting treatment of research and development in emerging markets, whose stock exchanges have been shown to not be highly correlated with the more developed markets, hence enables investors to diversify risk. This should motivate both managers and investors to venture beyond what the conservative accounting treatment of $\mathrm{R} \& \mathrm{D}$ has possibly instigated when valuing stocks.

Keywords: Accounting standards, Accounting treatment of R\&D, Glamour stocks, Intellectual capital, Stock market returns, Value relevance

Jel Codes: G14, M4, N27, O3

\section{Introduction}

Research and development (R\&D) forms an integral part of a firm's intangible investments, and signals a strengthening of a firm's competitiveness (Ballester, Garcia-Ayuso \& Livnat, 2003; Chan, 2012; Firer \& Williams, 2003; Lev, 1999). The practice of continuously developing and commercializing innovative products has proven to be a lucrative strategy for industry leaders, with companies such as Disney, Nintendo, Microsoft and Apple demonstrating that they are better equipped to compete against disruptive innovation by continually building intellectual capital (Habtay, 2012). R\&D thus plays an 
important role in stimulating innovation and economic growth, and has become critical to maintaining a competitive advantage in contemporary economies (Anagnostopoulou, 2008; Faff, Ho, Lin \& Yap, 2013; Li, 2012; Park, Chung \& Kim, 2014; Sorescu, Chandy \& Prabhu, 2003). The exact economic value of a $R \& D$ investment however, is difficult to determine, because of the risky nature of $R \& D$ and the uncertainty of the future benefit of a $R \& D$ activity. This uncertainty that is inherent in the investment's future financial performance, poses a dilemma of whether to expense or capitalize intangible assets.

Traditionally, the accounting standards required firms to expense R\&D expenditure in accordance with both the Generally Accepted Accounting Principles (GAAP) and the International Financial Reporting Standards (IFRS) (Bushee, 1998; Penman \& Zhang, 2012; Rubera \& Kirca, 2012). The International Accounting Standards Board (IASB) now distinguishes the research phase from the development phase, which enables the capitalization of the development component (Ballester et al., 2003). The responsibility however, is left with management to decide when to start capitalizing the development component, and/or whether it is to their advantage to disclose developmental information as a capital asset, or to continue to fully expense all R\&D. Since earnings are inflated when R\&D is expensed, managers may adopt short-term investment behavior to maintain earnings goals. The continuous practice and argument for expensing $\mathrm{R} \& \mathrm{D}$ lies in the inherent risk of the investment's future financial performance (Kothari, Laguerre \& Leone, 2002; Park et al., 2014; Penman \& Zhang, 2012). The expenses recorded are intended to act as expenditures utilized to generate income within the current financial period.

To this end, many studies have been conducted on the accounting treatment of $R \& D$, particularly the value-relevance of capitalizing $R \& D$. Accounting information is said to be value relevant if it has a component that can be explained or predicted by the current value of the stock (Barth, Beaver \& Landsman, 2001; Kimouche \& Rouabhi, 2016). Thefield of researchon the value-relevance of R\&D has its basis in the positive theory of accounting, which seeks to explain and predict the accounting practices of firms (Watts \& Zimmerman, 1990). The focus of extant research has been on the increased value-relevance of capitalizing $R \& D$ into a firm's asset base rather than expensing it in the income statement (Aboody \& Lev, 1998; Anagnostopoulou, 2008; Kothari et al., 2002; Park et al., 2014). This is mainly driven by the association proven in extant research between a R\&D investment and the future stock returns, as well as between the level of R\&D investment and subsequent abnormal excess returns (Bhana, 2013; Chambers, Jennings \& Thompson II, 2002; Chan, 2012; Chan, 
Lakonishok \& Sougiannis, 2001; Eberhart, Maxwell \& Siddique, 2004; Lev \& Sougiannis, 1996; Lev, Sarath \& Sougiannis, 2005).

Another reason to capitalize $R \& D$ is that the investment is often undertaken to improve a firm's performance beyond the current accounting period. Thus it should be treated like other capital expenditures, which are intended to enhance the performance of a company beyond the current period (Damodaran, 1999; Koller, Goedhart \& Wessels, 2010). Expensing R\&D is therefore in conflict with the intended purpose of a R\&D investment. As such, the resultant financial statement may not represent the future performance of a firm, since it does not take into consideration the dimension of time associated with its cost, its useful life, and cash generated by R\&D, which can be misleading. This often results in a firm showing conservative earnings in some periods and aggressive earnings in other periods (Lev, 2003), leading to the mispricing of an asset as investors are not able to correctly estimate the value of the firm's ability to generate cash flow.

The purpose of this research therefore was to investigate the impact of capitalization of $R \& D$ on the valuation of equities for firms listed on the Johannesburg Stock Exchange (JSE) in South Africa. The JSE is the oldest and most developed in Africa, and has demonstrated resilience in withstanding market turbulence. Most of the research on the accounting treatment of $\mathrm{R} \& \mathrm{D}$ is focused on the more developed markets and other developing markets. 33\% of the JSE shares however, are owned by foreign investors. The interest in emerging markets by foreign investors is a result of their low correlation with the more developed markets, which enables investors to diversify risk (Alagidede, 2011). The investment by foreigners in turn is expected to stimulate the country's economic growth and strengthen the stock market (Adam \& Tweneboah, 2009).

South African firms are required by law to use the reporting framework issued by the IASB, which allows the capitalization of the $R \& D$ component. It is however, still apparent that most firms completely expense R\&D as common practice (Bhana, 2013). This is possibly due to the difficulty in applying the rules for development expenditures, or is may be a result of the country's reliance on physical over intangible assets from its pre-apartheid days. South Africa though, is currently ahead of other African countries and its BRICS partners in terms of its domestic policies supporting global innovation, placing 30 out of 56 countries (Ezell, Nager \& Atkinson, 2016). For investment in intangibles to grow, and South Africa to become a competitive global player in the modern economy, the country's R\&D reporting needs to be value relevant. 
There is limited academic research that has been conducted in South Africa on the value relevance of expensing R\&D. Bhana's (2013) study, which used an event study methodology, showed that investors react to firms' R\&D announcements during the period 1995 to 2009. As argued by Chambers et al. (2002), accounting distortions provided using evidence from trading strategies are an indication of an inefficient market. Thus our goal in this paper was to provide evidence on the valuation of stocks for listed firms that report $R \& D$ in South Africa that may be a result of the accounting rules. This was investigated by contrasting the excess returns of R\&D stocks to other stocks with similar price-to-book and market size ratios to find any evidence of any post-investment excess returns and the association to the level of R\&D investment. In addition, we looked at the changes in excess returns after adjusting the book value as a result of capitalizing $\mathrm{R} \& \mathrm{D}$ expenditure, to see if the distortion imposed by expensing $\mathrm{R} \& \mathrm{D}$ contributed to the under-valuation of firms that invest in R\&D. The evidence collected and analyzed indicates a systematic under-valuation of R\&D firms. This should motivate both managers and investors to venture beyond what the conservative accounting treatment of R\&D has possibly instigated.

The rest of the paper is organized as follows. In the next section we review literature on the arguments that have been put forth for and against the capitalization of R\&D investments. This is then followed by a discussion on the methodology adopted to investigate the impact of not capitalizing R\&D for listed firms that reported R\&D on the JSE. The results are then discussed, and we then conclude based on the insights gathered from our results, and provide ideas for future research.

\section{Literature review}

\subsection{A case for $R \& D$ capitalization}

Research indicates that investment in $\mathrm{R} \& \mathrm{D}$ is significantly associated with an increase in subsequent market performance, and this is even more apparent in firms with high levels of R\&D (Lev \& Sougiannis, 1996). This corresponds to the notion that R\&D expenditure leads to improved operating performance over time, and thus, certain investors take this into consideration when valuing stocks (Eberhart et al., 2004; Lev \& Sougiannis, 1996; Pandit, Wasley \& Zach, 2011). Forecasts by financial analysts on R\&D investments however, are prone to a multitude of biases due to the nature of their uncertainty (Palmon \& Yezegel, 2012). R\&D levels are usually negatively correlated to the level of consensus between analysts' perceptions on its future benefit (Chambers, 2011; Dinh, Eierle, Schultze \& Steeger, 2015; Faff et al., 2013; Palmon \& Yezegel, 2012). Whilst evidence suggests that analysts have 
become more effective with their assessment of $\mathrm{R} \& \mathrm{D}$, forecast errors are still positively correlated to the level of R\&D (Chambers et al., 2002).

Among the literature that validates these excess returns, there are two groups of studies that generally take place: one group observes the positive correlation between the level of $\mathrm{R} \& \mathrm{D}$ investment and future excess return; the other looks at the association between the changes in the level of $\mathrm{R} \& \mathrm{D}$ expenditure and the observed future excess returns (Chambers et al., 2002). Both groups however, all point towards two common explanations for these relationships: that this phenomenon is either due to systematic mispricing or market compensation for the extra risk attached (Lev \& Sougiannis, 1996; Chan et al., 2001). The evidence put forth is that firms with large intangible capital have a smaller bookto-market ratio, since $R \& D$ investment is not recognized as an asset on the accounting balance sheet (Barth, Kasznik \& McNichols, 2001; Ballester et al., 2003; Fama \& French, 1993; Lev \& Sougiannis, 1996; Lev \& Sougiannis, 1999). This undervaluation and the uncertainty associated with the future performance of a firm, is what is attributed to the subsequent increase in market performance of firms invested in R\&D.

Firms that invest heavily in $\mathrm{R} \& \mathrm{D}$ are also likely to guard their competitive advantages and innovation strategies closely, since the both the GAAP and IFRS do not enforce disclosure on valuable information about these intangible assets. This protectiveness may distort information that inevitably eludes both competitors and investors alike about the expectations on the value or efficiency of such R\&D investment (Chan et al., 2001; Eberhart et al., 2004; García-Meca \& Martínez, 2007; Lev, 2003; Palmon \& Yezegel, 2012). Beyond the accounting implications described, Aboody and Lev (1998) also argue that the unique nature of $\mathrm{R} \& \mathrm{D}$ projects hinders investors' ability to make financial assumptions based on other firms' R\&D outcomes. Thus, even if markets generally react positively toward new $\mathrm{R} \& \mathrm{D}$ information or announcements, the effects of conservative accounting distortion and information asymmetry may lead them to initially mis-react to R\&D spending, effectively causing the capital market to act inefficiently.

\subsection{A case against $R \& D$ capitalization}

There are some challenges associated with capitalizing a R\&D investment. Evidence suggests that markets perceive the risk of a $R \& D$ investment to be on average three times larger than an investment on capital expenditure (Anagnostopoulou, 2008). Extant literature also points towards firms with higher R\&D intensity having greater systematic risk than less intensive firms due to business cycle 
fluctuations (Ciftci, Lev \& Radhakrishnan, 2009; Penman \& Zhang, 2012). Once the R\&D is complete, the success of its commercialization is highly dependent on the market condition at the time the investment decision is made, and the release window. The time lapse between the two makes relegating the mitigation of such risk improbable (Faff et al., 2013).

Capital risk due to the lack of collateral from a R\&D investment is also observed, where R\&D firms are more likely to have a non-optimal capital structure. Due to the uncertainty associated with such investments, the argument is that they cannot be utilized to issue debt (Damodaran, 1999; Faff et al., 2013). Thus, firms cannot set $R \& D$ as collateral for debt, as over-investment in R\&D can increase the cost of debt. This is due to the interest premium demanded by lenders for the lack of tangible or marketable collateral attached. Excessive capital allocation towards R\&D can also lead to underinvestment in other peripheral assets that act as an important support structure towards extracting additional value from R\&D, thus reducing the likelihood of commercial success (Prahalad \& Hamel, 1990). Therefore, management's unwillingness to increase the cost of capital, as well as the need to not disclose sensitive R\&D information to debt holders, further contributes to the likelihood of reaching an optimal capital structure - a scenario that is known to be penalized by the market (Chambers et al., 2002; Pandit et al., 2011).

A critical issue that current innovation-driven firms have with capitalizing $R \& D$ is that they may be discriminated against relative to other growth firms that do not invest heavily in R\&D. This is because of the reliance on price-to-book ratio to drive investment decisions, which does not reflect the intellectual capital under a firm's asset base. Furthermore, measures of profitability such as earningsper-share are often higher for non-R\&D growth firms, due to the GAAP reporting standards, or for those firms choosing to expense their R\&D investment (Wang, Du, Koong \& Fan, 2016). Capitalizing R\&D therefore does not allow these firms to be viewed on an equal footing. This results in management not being rewarded for their efforts for the long-term investment (Damodaran, 1999). The focus on accounting earnings over the significant positive correlation between R\&D investments and long-term shareholder returns is thus likely destroying future profitability as managers adopt shortterm investment behaviors to maintain earning goals. The evidence of this can be seen in a survey conducted by Duke University, in which $80 \%$ of the 400 sampled chief financial officers indicated they would 'reduce discretionary spending on potentially value-creating activities such as marketing and R\&D in order to meet their short-term earnings targets' (Koller et al., 2010, pp. 13).

To conclude, there is evidence that supports the positive association between R\&D expenditure and subsequent operating and market performance, indicating that this type of intangible investment is 
likely to have future commercial benefits (Eberhart et al., 2004; Lev \& Sougiannis, 1996; Pandit et al., 2011). However, the increasing gap in book-to-market ratios between R\&D and non-R\&D firms has drawn researchers to investigate the information on the intangible value that is prone to be concealed from investors as a result of expensing these intangible assets. This may inhibit the market in its ability to fully recognize the economic value that can be achieved by R\&D (Chen, Cheng \& Hwang, 2005). It is due to this paradigm that a substantial amount of research has been conducted to investigate the increasing value-relevance of capitalization R\&D over expensing R\&D.

\section{Research methodology}

\subsection{Data}

The data required for this study, firm specific operating financial data and the annualized stock prices for the corresponding firms, was obtained from a number of sources: Reuter's Data Stream, INET BFA and the Bloomberg online platforms. The annualized stock data corresponds to six month's post financial year-end (31st March for most firms in South Africa). This created a sufficient time-frame for the firms' annual financial statements to be audited and released for that year. It also provided a robust basis for earnings and $\mathrm{R} \& \mathrm{D}$ annualized comparison, based on the estimated release of publicly available information to investors.

The period under investigation for the research was for the 2000 to 2014 financial years. This corresponds to a period from six years after the international sanctions were officially lifted in South Africa, enabling the country to re-enter a global economy that is increasingly intellectual-capital based, to the latest completed financial reporting period. But since four years of prior R\&D data was needed in order to form the correct R\&D asset, the actual data collected was from 30th September 1996 to 30th September 2015. The indices collected were R\&D expenditure, sales, price-to-book, market price, and earnings before interest and tax (EBIT).

All listed firms (R\&D and non-R\&D) during this period were included in the data analysis to avoid survivorship bias. The effect of portfolio formation (explained later) eliminated the need for all firms to continuously exist throughout the entirety of the sample period. Two main assumptions pertaining to data retrieved were made. First, that the accounting reporting of $\mathrm{R} \& \mathrm{D}$ across firms is consistent. Second, for firms with intermittently omitted R\&D in their report, that such expenditure is zero for the non-disclosed period for the purpose of capitalization and amortization. 


\subsection{Data analysis}

In order to determine if the equity market systematically under-valued firms that invest in $\mathrm{R} \& \mathrm{D}$, the analysis proceeded in three phrases, using methods described by Ballester et al. (2003), Chambers et al. (2002), Chambers (2011), Chan et al. (2001), Eberhart et al. (2004), Fama and French (1993), and Lev and Sougiannis (1996).

\subsubsection{Data preparation for analysis}

The data preparation proceeded as follows for R\&D firms:

- First, 5 portfolios were formed by ranking the listed firms annually based on their R\&D intensity - defined in this research as R\&D expenditure relative to sales, a commonly used indicator of how much resources a firm dedicates to R\&D (Chan et al., 2001). A quintile is the de facto quantity utilized in most observed literature for ranking equally sized portfolios (Aboody \& Lev, 1998; Ballester et al., 2003; Chan et al., 2001; Ciftci et al., 2009; Lev \& Sougiannis, 1999; Park et al., 2014).

- Within each quintile the Fama and French (1993) size and book-to-market factors were applied. That is, firms were further ranked and divided into quintiles based on their book-to-market ratio and market capitalization respectively. This resulted in 25 portfolios.

A control group of 25 portfolios of non-R\&D listed firms with corresponding book-to-market and market capitalization was also formed, to be utilized as benchmarks for expected returns of each portfolio. Over the 20 year period the total number of firms included in each portfolio ranged from 106 to 350 for non-R\&D firms, and from 12 to 53 for R\&D firms.

\subsubsection{Excess returns}

Next, we needed to find evidence of post-investment excess returns (Equation 1) in firms that invest in R\&D. A firm i's annual excess return in year twas calculated as follows:

$$
E R_{i t}=\prod_{k=1}^{12}\left(1+R_{i k}\right)-\prod_{k=1}^{12}\left(1+R_{p k}\right)
$$


where $R_{i k}$ is the return for firm $i$ in month $k$, and $R_{p k}$ is the monthly return in benchmark portfolio $p$. The average excess returns for each $\mathrm{R} \& \mathrm{D}$ and non- $\mathrm{R} \& \mathrm{D}$ portfolio for one/two/three consecutive years post portfolio formation were then calculated over the period 2000 to 2014. The average book-tomarket and market capitalization of the annually rebalanced $R \& D$ portfolios were matched to the nonR\&D portfolios. This was calculated on the date of comparison (last trading day of September each year), and re-formed annually to insure up-to-date risk adjustments. Thus, the actual return of a firm, less the corresponding average non-R\&D control portfolio $\left(R_{p k}\right)$, formed the excess return under investigation.

\subsubsection{Excess returns of $R \& D$ firms based on recognised $R \& D$ capital}

The next step was to investigate if investors efficiently recognize R\&D investment as a capital asset. The book-to-market ratio needed to be compared to a fully capitalized R\&D as opposed to an expensed $\mathrm{R} \& \mathrm{D}$ asset. Under conservative accounting, firms with large $\mathrm{R} \& \mathrm{D}$ expenditure have small book-to-market ratios. Thus, if investors are efficient in their valuation of $\mathrm{R} \& \mathrm{D}$, and see past the conservative accounting imposed in the financial statements, then they will include R\&D capital in their assessment of a firm's book value. Following Chambers et al. (2002), Chan et al. (2001) and Lev and Sougiannis (1996), the current and past $\mathrm{R} \& \mathrm{D}$ expenditure, $\mathrm{R} D_{i t}$, was appropriately capitalized (Equation 2) using a five-year twenty percent straight-line approach as follows:

$$
R D C_{i t}=R D_{i t}+0.8 \times R D_{i t-1}+0.6 \times R D_{i t-2}+0.4 \times R D_{i \leftarrow-3}+0.2 \times R D_{i t-4}
$$

where $\mathrm{R} D C_{i t}$ represents the $\mathrm{R} \& \mathrm{D}$ capital for firm $i$ in year $t, \mathrm{R} D_{i t}$ is the unamortised $\mathrm{R} \& \mathrm{D}$ expenditure for firm $i$ in year $t$. The terms on the right in Equation 2 provide an estimate of the proportion of spending that is still productive in a given year over the past five year period. Based on the effect of the change in book value as a result of recognizing $R \& D$ capital, the $R \& D$ portfolios were then formed on the basis of size and adjusted book-to market ratios, and the excess returns were determined again using Equation 1. 


\section{Results and discussion}

\subsection{Evidence of post-investment excess returns and association to the level of $R \& D$ investment}

Table 1 shows the average excess returns (i.e., $R \& D$ stock returns benchmarked against non-R\&D stock returns) of the portfolios observed at one, two, and three years post portfolio formation from year 2000 to 2014. The first five columns report the excess average returns based on the level of R\&D intensity. There is no evident association between the level of $\mathrm{R} \& \mathrm{D}$ intensity and the excess returns experienced. The R\&D stocks however, bar the highest R\&D portfolio, have, on average, experienced abnormal returns above their benchmark portfolios in the buy-and-hold for two and three-year scenario, and these are highest for the middle portfolio. For the one-year return period, marginal differences are observed. These observations suggests that firms regard $\mathrm{R} \& \mathrm{D}$ as a long-term investment that is intended to create financial benefit beyond the current financial period (Damodaran, 1999; Koller et al., 2010). Investors therefore generally under-value the future returns of a R\&D stock at the time of investment, specifically in the long-term, which supports the notion that investors tend to make their investment decisions based on current earnings figures, and incorrectly ignore the future value of current R\&D expenditure (Ciftci et al., 2009). Subsequently, share prices tend to escalate when the benefit of R\&D investment is reflected in improved future earnings (Bhana, 2013).

\begin{tabular}{|c|c|c|c|c|c|c|c|}
\hline $\begin{array}{c}\text { Year following } \\
\text { investment date }\end{array}$ & $\begin{array}{c}1 \\
\text { (low R\&D) }\end{array}$ & 2 & 3 & 4 & $\begin{array}{c}5 \\
\text { (high R\&D) }\end{array}$ & $\begin{array}{c}\text { R\&D } \\
\text { (annualized) }\end{array}$ & $\begin{array}{l}\text { Non-R\&D } \\
\text { (annualized) }\end{array}$ \\
\hline One-year & $4.5 \%$ & $-8.6 \%$ & $8.3 \%$ & $0.4 \%$ & $-9.3 \%$ & $-0.9 \%$ & $-2.7 \%$ \\
\hline Two-year & $23.9 \%$ & $5.7 \%$ & $23.9 \%$ & $15.5 \%$ & $-20.8 \%$ & $4.7 \%$ & $1.8 \%$ \\
\hline Three-year & $37.0 \%$ & $22.1 \%$ & $46.5 \%$ & $35.8 \%$ & $-37.9 \%$ & $6.5 \%$ & $3.8 \%$ \\
\hline Average & $21.8 \%$ & $6.4 \%$ & $26.2 \%$ & $17.2 \%$ & $-22.7 \%$ & $3.4 \%$ & $1.0 \%$ \\
\hline
\end{tabular}

Table 1. Average excess returns of R\&D stocks from year 2000 to 2014 grouped by R\&D intensity (Chan et al., 2001)

The highest R\&D intensity portfolio (portfolio 5) earns substantially negative excess returns $(-22.7 \%$ ) compared to the overall average of $3.4 \%$ for all R\&D firms. Extant literature suggests that high R\&D stocks tend to be 'glamour stocks'. That is, stocks having a lower book-to-market ratio, and also historically showing lower returns (Chan et al., 2001; Damodaran, 1999; Fama \& French, 1993; Koller et al., 2010; Lev \& Sougiannis, 1999). We can see from Table 2 that the book-to-market (B/M) ratios decrease as $\mathrm{R} \& \mathrm{D}$ intensity increases on average, with portfolio 5 having the lowest average $\mathrm{B} / \mathrm{M}$ ratio (0.61), and portfolio 1 , the highest average $\mathrm{B} / \mathrm{M}$ ratio (0.88). Table 3 shows the potential impact of 
expensing R\&D on book value for the six highest R\&D-intensive sectors in 2014. The low book-tomarket ratios indicate investor's expectations of the anticipated value from the R\&D investment. The percentage change between the adjusted book value is also expressed, showing the possible distortion that conventional accounting indicators may impose on investors. Expensing of R\&D thus has a material effect on the intrinsic value, eluding investors that specifically target low book-to-market stocks. These stocks will appear to be of a lower book value than what it should be considered at, resulting in over-priced stocks, and hence the negative returns.

\begin{tabular}{|c|c|c|c|c|c|}
\hline Year & $\begin{array}{c}1 \\
\text { (low R\&D) }\end{array}$ & 2 & 3 & 4 & $\begin{array}{c}5 \\
\text { (high R\&D) }\end{array}$ \\
\hline 2000 & 0.82 & 1.17 & 0.51 & 0.82 & 0.55 \\
\hline 2001 & 2.18 & 0.96 & 1.19 & 0.44 & 0.83 \\
\hline 2002 & 1.02 & 1.11 & 0.86 & 0.83 & 0.42 \\
\hline 2003 & 0.82 & 0.98 & 0.88 & 0.59 & 0.43 \\
\hline 2004 & 1.32 & 0.76 & 0.62 & 0.72 & 0.80 \\
\hline 2005 & 0.73 & 0.51 & 0.55 & 0.67 & 0.70 \\
\hline 2006 & 0.48 & 0.59 & 0.48 & 0.48 & 0.56 \\
\hline 2007 & 0.36 & 0.40 & 0.49 & 0.40 & 0.43 \\
\hline 2008 & 0.32 & 0.53 & 0.61 & 0.44 & 0.47 \\
\hline 2009 & 0.83 & 1.01 & 0.85 & 0.70 & 0.57 \\
\hline 2010 & 0.97 & 0.89 & 0.64 & 0.71 & 0.57 \\
\hline 2011 & 0.97 & 0.59 & 0.92 & 0.76 & 0.50 \\
\hline 2012 & 1.06 & 1.25 & 0.70 & 0.66 & 0.61 \\
\hline 2013 & 0.73 & 0.58 & 0.65 & 0.65 & 0.66 \\
\hline 2014 & 0.61 & 0.61 & 0.52 & 0.63 & 1.11 \\
\hline Average & 0.88 & 0.80 & 0.70 & 0.64 & 0.61 \\
\hline
\end{tabular}

Table 2. Book-to-market ratio of R\&D stocks from year 2000 to 2014 grouped by R\&D intensity

\begin{tabular}{|l|r|r|r|}
\cline { 2 - 4 } \multicolumn{1}{c|}{} & B/M & Adjusted B/M & \% change of B/M \\
\hline Chemical & 0.46 & 0.47 & $-1.41 \%$ \\
\hline Diversified Industrials & 0.91 & 0.91 & $0.00 \%$ \\
\hline Electrical and electronic equipment & 0.95 & 0.96 & $-0.96 \%$ \\
\hline Food processors & 0.48 & 0.49 & $-0.97 \%$ \\
\hline Industrial mining & 1.08 & 1.10 & $-2.20 \%$ \\
\hline Pharmaceutical & 0.33 & 0.34 & $-2.69 \%$ \\
\hline
\end{tabular}

Table 3. The effect on book-to-market ratio from capitalising R\&D for the year 2014 for high intensive $R \& D$ sectors

Thus, whilst we do not observe any apparent association between the level of R\&D investment and post-investment excess returns, overall, R\&D stocks performed better than non-R\&D stocks at one, two, and three years post portfolio formation from year 2000 to 2014, with the exception of portfolio 5 
(highest $\mathrm{R} \& \mathrm{D}$ intensity). The $\mathrm{R} \& \mathrm{D}$ stocks also performed better on average than non-R\&D stocks (last two columns of Table 1), an indication that the market is not fully accounting for the future benefit of the $R \& D$ investment. The highest $R \& D$ intensity stocks (portfolio 5) are the quintessential glamour stocks, an indication that there is more value in the lower R\&D-intensive firms compared to the affluent R\&D firms. As research by García-Meca and Martínez (2007) illustrated, the use of R\&D information by financial analysts is more prominent in profitable firms. This suggests that investors potentially overlook the value inherent in other smaller firms undertaking $R \& D$.

\subsection{Excess returns of $R \& D$ firms based on recognised $R \& D$ capital}

The excess returns observed in Table 4, based on adjusted book-to-market ratios, indicate a similar pattern to that observed in Table 1. There is no apparent association between the level of R\&D intensity and the adjusted excess returns experienced, and the R\&D stocks have, bar the highest $\mathrm{R} \& \mathrm{D}$ portfolio, on average, experienced abnormal returns above their benchmark portfolios.

\begin{tabular}{|l|r|r|r|r|r|r|r|}
\hline $\begin{array}{c}\text { Year following } \\
\text { investment date }\end{array}$ & $\begin{array}{c}1 \\
\text { (low R\&D) }\end{array}$ & \multicolumn{1}{c|}{$\mathbf{2}$} & \multicolumn{1}{c|}{$\mathbf{3}$} & \multicolumn{1}{c|}{$\mathbf{4}$} & $\begin{array}{c}\mathbf{5} \\
\text { (high R\&D) }\end{array}$ & $\begin{array}{c}\text { R\&D } \\
\text { (annualized) }\end{array}$ & $\begin{array}{c}\text { Non-R\&D } \\
\text { (annualized) }\end{array}$ \\
\hline One-year & $5.8 \%$ & $-8.2 \%$ & $8.3 \%$ & $1.0 \%$ & $-12.4 \%$ & $-1.1 \%$ & $-2.7 \%$ \\
\hline Two-year & $26.8 \%$ & $4.8 \%$ & $23.9 \%$ & $15.5 \%$ & $-17.0 \%$ & $5.3 \%$ & $1.8 \%$ \\
\hline Three-year & $40.2 \%$ & $22.4 \%$ & $46.5 \%$ & $35.8 \%$ & $-33.9 \%$ & $6.9 \%$ & $3.8 \%$ \\
\hline Average & $24.3 \%$ & $6.3 \%$ & $26.2 \%$ & $17.4 \%$ & $-21.1 \%$ & $3.7 \%$ & $1.0 \%$ \\
\hline
\end{tabular}

Table 4. Average excess returns of R\&D stocks from year 2000 to 2014, based on adjusted book value, grouped by R\&D intensity (Chan et al., 2001)

The change in excess returns across all portfolios, whilst mainly positive, has been relatively minor (refer to Table 5). The most noticeable changes occur at both ends of the R\&D intensity spectrum (portfolios 1 and 5), with portfolio 1 experiencing the most change in its excess returns at 2.5\% on average above the un-adjusted excess returns. This could be an indication of the investors underestimating the future benefits associated with firms that do not spend heavily on $R \& D$. On average however, we observe a slight increase in annualized positive excess returns $(0.3 \%)$ after bookto-market adjustment. This suggests that the market does not factor in R\&D expenditure as an asset, hence the tendency to misprice $\mathrm{R} \& \mathrm{D}$ stocks is indeed motivated by accounting book-value distortions. 


\begin{tabular}{|l|r|r|r|r|r|r|}
\hline \multicolumn{1}{|c|}{$\begin{array}{c}\text { Year following } \\
\text { investment date }\end{array}$} & $\begin{array}{c}\text { 1 } \\
\text { (low R\&D) }\end{array}$ & \multicolumn{1}{c|}{$\mathbf{2}$} & \multicolumn{1}{c|}{$\mathbf{3}$} & \multicolumn{1}{c|}{$\mathbf{4}$} & $\begin{array}{c}\text { 5 } \\
\text { (high R\&D) }\end{array}$ & $\begin{array}{c}\text { Average } \\
\text { (annualised) }\end{array}$ \\
\hline One-year & $1.0 \%$ & $0.4 \%$ & $0.0 \%$ & $0.6 \%$ & $-3.1 \%$ & $-0.2 \%$ \\
\hline Two-year & $2.9 \%$ & $-0.9 \%$ & $0.0 \%$ & $0.0 \%$ & $3.8 \%$ & $0.6 \%$ \\
\hline Three-year & $3.2 \%$ & $0.2 \%$ & $0.0 \%$ & $0.0 \%$ & $4.1 \%$ & $0.4 \%$ \\
\hline Average & $2.5 \%$ & $-0.1 \%$ & $0.0 \%$ & $0.2 \%$ & $1.6 \%$ & $0.3 \%$ \\
\hline
\end{tabular}

Table 5. Change in excess returns of R\&D stocks from year 2000 to 2014, due to adjusted book value grouped by R\&D intensity (Chan et al., 2001)

\section{Conclusion}

The purpose of this research was to determine the impact of valuing R\&D stocks on the JSE, in order to determine if investors price the value of $R \& D$ expenditure into the stock price. A majority of firms in South Africa still choose to expense all their R\&D, because historically, the country relied heavily on labour and natural resources. Thus we wished to establish if investors generally misprice firms that participate in $\mathrm{R} \& \mathrm{D}$, and if the conservative accounting standards that govern how firms can report on their R\&D contributes to this mispricing. Our investigation covered the sample period from year 2000 to 2014, focusing on short-term and long-term buy-and-hold excess returns of R\&D firms for one, two, and three years post portfolio formation.

Our findings align with past research, indicating that firms that invest in $\mathrm{R} \& \mathrm{D}$ experience a noticeable level of positive (risk-adjusted) excess returns, and actually out-perform non-R\&D stocks in the long term. The post investment excess returns are an indication that the accounting reporting of R\&D by firms is not fully informative across the full sample. Unlike some of the prior studies, we did not find evidence of any association between the level of R\&D investment and post-investment excess returns, but found evidence of the glamour stock phenomenon in highly intensive R\&D firms. Thus the returns are higher for less intensive R\&D firms than for the highly intensive R\&D firms. The book-tomarket ratios decrease as the level of $\mathrm{R} \& \mathrm{D}$ intensity increases on average, hence the use of accounting indicators such as book value may be eluding investors that specifically target low book-to-market stocks, or those who only consider R\&D information in profitable firms. The findings from this research thus imply that potential investors should consider investing in firms that have undertaken $\mathrm{R} \& \mathrm{D}$ since these earn excess (risk-adjusted) returns, but should avoid over-pricing highly intensive $\mathrm{R} \& \mathrm{D}$ firms with low book value, as these will lead to earning negative returns. Glamour stocks are typically popular among investors, who potentially miss the value inherent in the other R\&D stocks when examining financial reports. 
Lastly, there needs to be more consideration in how R\&D expenditure is treated in the financial statements. Capitalizing the development phase as afforded by the IASB lacks standardization, and as such, inconsistencies arise in the earnings reflected on companies' financial statements. Other factors such as the history of success of a firm with $R \& D$, proven $R \& D$ concepts, and the riskiness of the asset, need to be taken into consideration, as the R\&D benefit is intended for and experienced beyond the current financial period.

There are different avenues for further research. Since South Africa is mainly a labor and commoditybased economy, listed firms whose main focus is on building intangible assets, are relatively few, hence the descriptive nature of our research. If the number of listed firms were to grow in the future, continuing the research on a more recent sample using robust methodology, as well as ensuring sector neutrality and incorporating industry-specific capitalization rates of the various $R \& D$ assets in future research, could help better understand the impact of $R \& D$ on firm value. Different market conditions also lend themselves to varying levels of information asymmetry (Cormier, Houle \& Ledoux, 2013), with firms likely to closely guard their competitive advantages and innovation strategies when the economy declines. The valuation of $\mathrm{R} \& \mathrm{D}$ listed firms is also not immune to over-investment derived from bullish market conditions. Thus future research could compare the accounting distortion of immediately expensing $\mathrm{R} \& \mathrm{D}$ during times of crises, a period immediately following the crisis, and periods of certainty, to determine the extent of the distortion under the different market conditions.

The portfolio with the highest $\mathrm{R} \& \mathrm{D}$ intensity actually stands out as being systematically over-valued by investors. Besides the accounting indicators, previous successes of these firms may explain the optimism by investors, thus another avenue for further research is to look at the relationship between investor confidence and $R \& D$ valuation. Lower $R \& D$ intensity firms could be impacted more by sales volatility than high $\mathrm{R} \& \mathrm{D}$ intensity firms, thus future research utilising different $\mathrm{R} \& \mathrm{D}$ intensity definitions (e.g. R\&D expenditure relative to market price or book value) may prove to be insightful. With a larger sample, future studies could also compare and contrast the results to other developing countries, especially since the glamour effect phenomemon is not common in these types of research. Finally, Gong and Wang (2016) have shown the decline in the value relevance of R\&D expenses post the adoption of the IFRS, thus it will also be of interest in the future to see how long it takes for this phenomenon to occur in South Africa. 


\section{References}

Aboody, D., \& Lev, B. (1998). The value relevance of intangibles: The case of software capitalization. Journal of Accounting Research, 36, 161-191. https://doi.org/10.2307/2491312

Adam, M., \& Tweneboah, A. (2009). Foreign Direct Investment and Stock Market Development: Ghana's Evidence. International Research Journal of Finance and Economics, 26, 178-185.

Alagidede, P. (2011), Return behaviour in Africa's emerging equity markets. The Quarterly Review of Economics and Finance, 51(2), 133-140. https://doi.org/10.1016/j.qref.2011.01.004

Anagnostopoulou, S.C. (2008). R\&D expenses and firm valuation: A literature review. International Journal of Accounting and Information Management, 16(1), 5-24. https://doi.org/10.1108/18347640810887735

Ballester, M., Garcia-Ayuso, M., \& Livnat, J. (2003). The economic value of the R\&D intangible asset. European Accounting Review, 12(4), 605-633. https://doi.org/10.1080/09638180310001628437

Barth, M.E., Beaver, W.H., \& Landsman, W.R. (2001). The relevance of the value relevance literature for financial accounting standard setting: another view. Journal of Accounting and Economics, 31(1), 77-104. https://doi.org/10.1016/S0165-4101(01)00019-2

Barth, M.E., Kasznik, R., \& McNichols, M.F. (2001). Analyst coverage and intangible assets. Journal of Accounting Research, 39(1), 1-34. https://doi.org/10.1111/1475-679X.00001

Bhana, N. (2013). The valuation of research and development expenditures: The case for companies listed on the Johannesburg Stock Exchange. International Journal of Finance and Policy Analysis, 5(2), $3-5$.

Bushee, B.J. (1998). The influence of on institutional R\&D behavior investors myopic investment. The Accounting Review, 73(3), 305-333.

Chambers, D. (2011). Discussion of "Is research and development mispriced or properly risk adjusted?". Journal of Accounting, Auditing \& Finance, 26(1), 117-120.

https://doi.org/10.1177/0148558X11400582

Chambers, D., Jennings, R., \& Thompson II, R.B. (2002). Excess returns to R\&D-intensive firms. Review of Accounting Studies, 7(2-3), 133-158. https://doi.org/10.1023/A:1020217817156

Chan, A.L.C. (2012). Innovation activity and corporate financing: Evidence from a developing economy. Applied Financial Economics, 22(20), 1665-1678. https://doi.org/10.1080/09603107.2012.667547

Chan, L.K.C., Lakonishok, J., \& Sougiannis, T. (2001). The stock market valuation of research and development expenditures. Journal of Finance, 56(6), 2431-2456. https://doi.org/10.1111/0022-1082.00411 
Chen, M.C., Cheng, S.J., \& Hwang, Y. (2005). An empirical investigation of the relationship between intellectual capital and firms' market value and financial performance. Journal of Intellectual Capital, 6(2), 159-176. https://doi.org/10.1108/14691930510592771

Ciftci, M., Lev, B., \& Radhakrishnan, S. (2009). Is research and development mispriced or properly risk adjusted?. Journal of Accounting, Auditing \& Finance, 26(1), 81-116. https://doi.org/10.1177/0148558X11400581

Cormier, D., Houle, S., \& Ledoux, M.J. (2013). The incidence of earnings management on information asymmetry in an uncertain environment: Some Canadian evidence. Journal of International Accounting, Auditing and Taxation, 22(1), 26-38. https://doi.org/10.1016/j.intaccaudtax.2013.02.002

Damodaran, A. (1999). Research and development expenses: Implications for profitability measurement and valuation. Working Paper No. FIN-99-024, Stern School of Business, New York University.

Dinh, T., Eierle, B., Schultze, W., \& Steeger, L. (2015). Research and development, uncertainty, and analysts' forecasts: The case of IAS 38. Journal of International Financial Management \& Accounting, 26(3), 257-293. https://doi.org/10.1111/jifm.12029

Eberhart, A.C., Maxwell, W.F., \& Siddique, A.R. (2004). An examination of long-term abnormal stock returns and operating performance following R\&D increases. Journal of Finance, 59, 623-650. https://doi.org/10.1111/j.1540-6261.2004.00644.x

Ezell, S.J., Nager, A.B., \& Atkinson, R.D. (2016). Contributors and Detractors: Ranking Countries' Impact on Global Innovation. Retrieved from: http://www2.itif.org/2016-contributors-and-detractors.pdf? $\mathrm{ga}=1.257774862 .421061582 .1464445548$

Faff, R., Ho, Y.K., Lin, W., \& Yap, C.M. (2013). Diminishing marginal returns from R\&D investment: Evidence from manufacturing firms. Applied Economics, 45(5), 611-622. https://doi.org/10.1080/00036846.2011.608644

Fama, E.F., \& French, K.R. (1993). Common risk factors in the returns on stocks and bonds. Journal and Financial Economics, 33(1), 3-56. https://doi.org/10.1016/0304-405X(93)90023-5

Firer, S., \& Williams, S.M. (2003). Intellectual capital and traditional measures of corporate performance. Journal of Intellectual Capital, 4(3), 348-360. https://doi.org/10.1108/14691930310487806

García-Meca, E., \& Martínez, I. (2007). The use of intellectual capital information in investment decisions: An empirical study using analyst reports. The International Journal of Accounting, 42(1), 57-81. https://doi.org/10.1016/j.intacc.2006.12.003 
Gong, J.J., \& Wang, S.I. (2016). Changes in the value relevance of research and development expenses after IFRS adoption. Advances in Accounting. Advance online publication.

https://doi.org/10.1016/j.adiac.2016.05.002

Habtay, S.R. (2012). A firm-Level analysis on the relative difference between technology-driven and market-driven disruptive business model innovations. Creativity and Innovation Management, 21(3), 290-303. https://doi.org/10.1111/j.1467-8691.2012.00628.x

Kimouche, B., \& Rouabhi, A. (2016). The impact of intangibles on the value relevance of accounting information: Evidence from French companies. Intangible Capital, 12(2), 506-529. https://doi.org/10.3926/ic.653

Koller, T., Goedhart, M., \& Wessels, D. (2010). Valuation: Measuring and managing the value of companies (5th ed.). Hoboken, NJ: John Wiley

Kothari, S.P., Laguerre, T.E., \& Leone, A.J. (2002). Capitalization versus expensing: Evidence on the uncertainty of future earnings from capital expenditures versus $\mathrm{R} \& \mathrm{D}$ outlays. Review of Accounting Studies, 7(4), 355-382. https://doi.org/10.1023/A:1020764227390

Lev, B. (1999). The inadequate public information on intellectual capital and its consequences. Conference presentation at the International Symposium, Measuring and Reporting Intellectual Capital: Experiences, Issues, and Prospects, Amsterdam, Holanda, Organisation for Economic Cooperation and Development 9-10 June.

Lev, B. (2003). Remarks on the measurement, valuation, and reporting of intangible assets. Economic Policy Review, 9(3), 17-22.

Lev, B., Sarath, B., \& Sougiannis, T. (2005). R\&D reporting biases and their consequences. Contemporary Accounting Research, 22(4), 977-1026. https://doi.org/10.1506/7XMH-QQ74-L6GG-CJRX

Lev, B., \& Sougiannis, T. (1996). The capitalization, amortization, and value-relevance of R\&D. Journal of Accounting and Economics, 21(1), 107-138. https://doi.org/10.1016/0165-4101(95)00410-6

Lev, B., \& Sougiannis, T. (1999). Penetrating the book-to-market black box: The R\&D effect. Journal of Business Finance \& Accounting, 26(3-4), 419-449. https://doi.org/10.1111/1468-5957.00262

Li, W.C.Y. (2012). Depreciation of business R\&D capital. Bureau of Economic Analysis/National Science Foundation R\&D Satellite Account Paper, Washington D. C.

Palmon, D., \& Yezegel, A. (2012). R\&D intensity and the value of analysts' recommendations. Contemporary Accounting Research, 29(2), 621-654. https://doi.org/10.1111/j.1911-3846.2011.01117.x 
Pandit, S., Wasley, C.E., \& Zach, T. (2011). The effect of research and development (R\&D) inputs and outputs on the relation between the uncertainty of future operating performance and R\&D expenditures. Journal of Accounting, Auditing \& Finance, 26(1), 121-144.

https://doi.org/10.1177/0148558X11400583

Park, C.K., Chung, S.G., \& Kim, J.W. (2014). Accounting for R\&D expenditure: To capitalize or not to capitalize. Life Science Journal, 11(7), 107-111.

Penman, S.H., \& Zhang, X.J. (2012). Accounting the quality stock of conservatism, earnings, returns and stock returns. The Accounting Review, 77(2), 237-264. https://doi.org/10.2308/accr.2002.77.2.237

Prahalad, C.K., \& Hamel, G. (1990). The core competence of the corporation. Harvard Business Review, 68(3), 79-91.

Rubera, G., \& Kirca, A.H. (2012). Firm innovativeness and its performance outcomes: A meta-analytic review and theoretical integration. Journal of Marketing, 76(3), 130-147.

https://doi.org/10.1509/jm.10.0494

Sorescu, A.B., Chandy, R.K., \& Prabhu, J.C. (2003). Sources and financial consequences of radical innovation: Insights from pharmaceuticals. Journal of Marketing, 67(4), 82-102.

https://doi.org/10.1509/jmkg.67.4.82.18687

Wang, Y., Du, R., Koong, K.S., \& Fan, W. (2016). Effects of R\&D policy choice on accounting performance and market value. R\&D Management. Advance online publication.

https://doi.org/10.1111/radm.12225

Watts, R.L., \& Zimmerman, J.L. (1990). Positive accounting theory: A ten year perspective. Accounting Review, 65(1), 131-156.

Intangible Capital, 2017 (www.intangiblecapital.org)

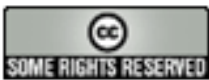

Article's contents are provided on an Attribution-Non Commercial 3.0 Creative commons license. Readers are allowed to copy, distribute and communicate article's contents, provided the author's and Intangible Capital's names are included. It must not be used for commercial purposes. To see the complete license contents, please visit http://creativecommons.org/licenses/by-nc/3.0/. 